\title{
Analysis of the Investment in Wood Processing and Furniture Manufacturing Entities by Key Factors of Competitiveness
}

\section{Analiza investicijskih ulaganja proizvodnih subjekata prerade drva i proizvodnje namještaja primjenom ključnih čimbenika konkurentnosti}

\author{
Review paper $\bullet$ Pregledni rad \\ Received-prispjelo: 16. 7. 2012. \\ Accepted-prihvaćeno: 15. 2. 2013. \\ UDK: $630 * 79 ; 330.32: 674.2: 684$ \\ doi:10.5552/drind.2013.1235
}

\begin{abstract}
Processing of wood and manufacture of wood and cork products, excluding furniture, manufacture of straw and plaiting goods (C16) and manufacture of furniture (C31) were the most competitive activities of the Republic of Croatia in the European market in the late 1980s and early 1990s. Those activities began losing their market share at the end of 1994, and no significant positive change in market competitiveness has been recorded since then. The question is how to achieve and maintain competitiveness, which is the condition of survival in an increasingly demanding environment. Preliminary and previous research on investments points to the assumption that the problem of competitiveness in the observed economic branch essentially boils down to a problem in the quality and efficiency of the investments of associated business entities. This paper tries to give answers to the following questions: What is the investment policy, is there an internal factor for lagging behind in competitiveness, what the other reasons are and how competitiveness can be achieved. By analyzing the investment in key factors of competitiveness in the period 2007 to 2010, consistently established by this paper, the existing data on investment of wood processing and furniture manufacturing entities will be identified, and an AHP investment model will be proposed that takes into account the simultaneous influence of all of the key factors of competitiveness and is the best indicator of the direction to be taken, with the final aim of achieving competitiveness.
\end{abstract}

Key words: wood processing, furniture manufacturing, AHP investment model, competitiveness

SAŽETAK • Prerada drva i proizvoda od drva i pluta, osim namještaja; proizvodnja proizvoda od slame i pletarskih materijala (C16) i proizvodnja namještaja (C31) Republike Hrvatske u kasnim 1980-ima i ranim 1990-im godinama bili su konkurentna aktivnost na europskom tržištu. Nakon 1994. godine te djelatnosti počinju gubiti

\footnotetext{
Author is Doctor of Science, Head of Sector, Ministry of Regional Development, Forestry and Water Management, Croatia. ${ }^{2}$ Authors are assistant and professors at Faculty of Forestry, University of Zagreb, Croatia. ${ }^{3}$ Author is associate professor at Biotechnical Faculty, University of Ljubljana, Slovenia.

Autorica je doktorica znanosti, načelnica sektora, Ministarstvo regionalnog razvoja, šumarstva i vodnoga gospodarstva, Republika Hrvatska. ${ }^{2}$ Autori su viša asistentica i profesori Šumarskog fakulteta Sveučilišta u Zagrebu, Republika Hrvatska. ${ }^{3}$ Autor je izvanredni profesor Biotehničkog fakulteta Sveučilišta u Ljubljani, Republika Slovenija.
} 
svoje tržišne udjele i do danas nije zabilježena znatnija pozitivna promjena tržišne konkurentnosti. Postavlja se pitanje kako ostvariti i održati konkurentnost, što je uvjet opstanka u sve zahtjevnijem okruženju. Preliminarna i prethodna istraživanja investicijske aktivnosti upućuju na pretpostavku da se problem konkurentnosti promatranoga gospodarstva u osnovi svodi na problem kvalitete i učinkovitosti investicijskih ulaganja pripadajućih gospodarskih subjekata. Kakva je investicijska politika i je li ona unutarnji čimbenik zaostajanja u konkurentnosti, koji su drugi razlozi i kako postići konkurentnost, pitanja su na koja odgovor daje ovaj rad. Analizom ulaganja u ključne čimbenike konkurentnosti u razdoblju od 2007. do 2010. godine, konzistentno utvrdene ovim radom, identificirat će se postojeći model investicijskih ulaganja gospodarskih subjekata prerade drva i proizvodnje namještaja te predložiti AHP model investicijskih ulaganja koji uzima u obzir istodobni utjecaj svih ključnih čimbenika konkurentnosti i najbolji je pokazatelj u kojem smjeru treba krenuti radi postizanja konačnog ciljaosiguranja konkurentnosti.

Ključne riječi: prerada drva, proizvodnja namještaja, AHP model investicijskih ulaganja, konkurentnost

\section{INTRODUCTION}

\section{UVOD}

Wood processing and manufacture of wood and cork products, excluding furniture, the manufacture of straw and plaiting goods (C16) and manufacture of furniture (C31) were the most competitive activities of the Republic of Croatia in the European market in the late 1980s and early 1990s. C16 and C31 are tags for wood processing sectors according to National Classification of Activities - Nacionalna Klasifikacija Djelatnosti (NKD, 2007). These activities began losing their market share at the end of 1994, and no significant positive change in market competitiveness has been recorded since then.

It is a generally accepted fact that socioeconomic development greatly depends on investment, and therefore long-term development can only be achieved through investment, because well targeted investment activity is the primary assumption for all aspects of competitiveness. The above mentioned context makes the problem of investing in wood processing and furniture manufacturing more complicated.

Due to the importance of the observed economic branches and the necessity of adapting to new market relations, a need to establish the key factors of competitiveness in terms of investment arises.

The specific characteristics of wood processing and furniture manufacturing are based on a SWOT analyses and recommendations in the strategic and development documents of the Government of the Republic of Croatia and the European Union (2004). A short analysis of the relative importance of the key factors of competitiveness in wood processing and furniture production provides the justification for investing in those key factors, which comprise of: $f 1$ - staff education, $f 2$ - marketing and promotional activities, $f 3$ - products, services and production processes innovation, $f 4$ - wood processing and furniture manufacturing technology, $f 5$ - environmental protection technology, $f 6$ - energy efficiency technology, $f 7$ - spatial capacities.

Two pilot studies (Debelić et al., 2009a and Debelić et al., 2009b) warned about the lack of investment policy for wood processing and furniture manufacture and provided a starting point for the assumption that the orientation and quality of investment is ques- tionable. This paper deals with the research of vindication of the aforementioned subject.

This paper also presents the analysis of competitiveness of wood processing and furniture manufacturing and of the influence of the global economic recession on their operations. This will further add to the vindication of investment in support of competitiveness as well as to the justification of investment in support of the country's regional development.

The main goal of the study is to create an optimizing and efficient investment model that will have practical application in wood processing and furniture manufacturing (Ojurović, 2010).

\section{MATERIAL AND METHODS}

\section{MATERIJAL I METODE}

The method was chosen on the basis of the problem, goals and tasks: selection and classification of the sample, choice of the method and instruments of the research, collection and processing of the data.

The goal will be accomplished through a comparison of the existing state and the investment model, gained by applying the selected mathematical methods.

\subsection{Selection and classification of the sample 2.1. Izbor i klasifikacija uzorka}

By analyzing the data, it was established that in practice the majority of business entities do not actually conduct their officially registered activity, according to NKD 2007 (theoretical classification).

Based on the non-sustainability of these classifications and in order to obtain results that would provide a realistic picture of the priority of investments by organizing them according to the specific area of the investor, which is not the case considering the presented shares of the investors, the acceptability of the empirical starting point was established. In order to set the empirical starting point of the classification of the sample and using the facts that confirm the unacceptability of the theoretical classification, two criteria were defined:

Criterion 1: Finished wood products, the definition and content using customs tariff numbers,

Criterion 2: Technological complexity of the product. 


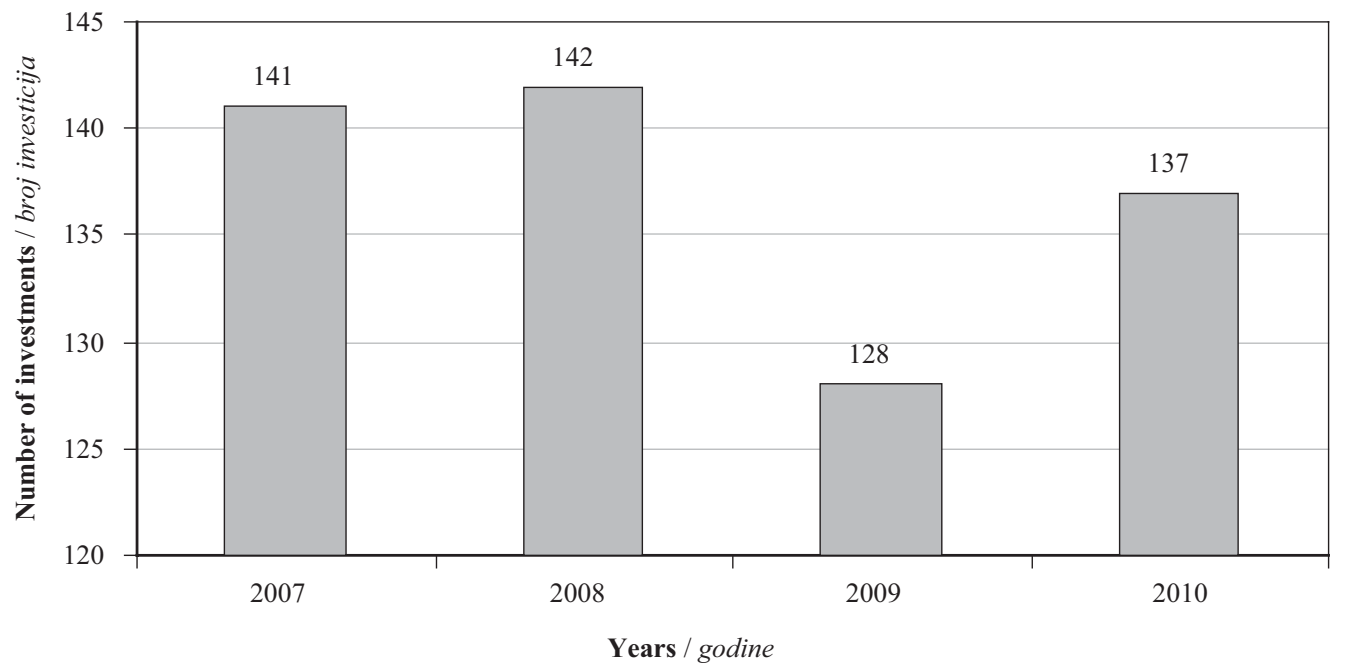

Figure 1 Number of investments per year in the period 2007 to 2010

Slika 1. Broj investicijskih ulaganja po godinama u razdoblju od 2007. do 2010.

According to the empirical starting point, the sample is classified into three subareas of the population:

1. Primary product $(\mathrm{PP})$ - sawn timber, elements,

2. Semi-finished product (SF) - veneer, palettes, packaging, wood houses, briquettes, parquets, floor and ceiling lining,

3. Finished product (FP) - furniture, finished parquet, wood accessories, construction joinery, funeral equipment.

The selection method for units of the sample is stratified sampling. By choosing from the population subareas (PP, SF and FP) and after several selections by means of analyzing the acceptability while taking into account the character of the research and analyzing the investments per investor, 548 investments were gained without annual repetition in the period 2007 to 2010, which represents the size of the research sample and the basis for establishing the existing investment model of wood processing and furniture manufacturing entities (Figure 1).

Sorting the investments according to subareas, the largest number of them (309) belongs to subarea FP. This is logical when the need for systematic and diverse investment in the structure of production of

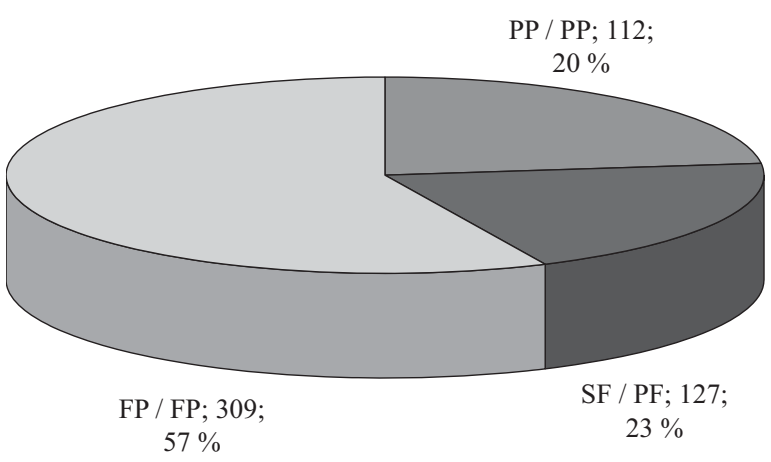

Figure 2 Number of investments per subarea in the period 2007 to 2010

Slika 2. Broj investicijskih ulaganja prema područjima u razdoblju od 2007. do 2010. goods with a higher level of finalization is taken into account, and it also demonstrates the limited investment in subarea PP. The ratio in favour of PF and FP, which together give a size of 436 units (investments), when compared to the 112 PP units, affirms the quality of the sample (Figure 2).

\subsection{Choice of method and instruments of research \\ 2.2. Izbor metode i instrumenata istraživanja}

In all areas of business, at higher levels of decision-making, the process of making decisions, according to their characteristics, belongs to multi-criteria decision-making. Decisions connected to situations in the business environment depend on a large number of mutually-connected and often entirely conflicting criteria. The problem that arises is how to correctly evaluate the importance of the factors and how to create a priority system that can lead to good decisions when choosing the best alternatives. The best known methods for comparing and ranking alternatives in decisionmaking problems are ELECTRE, PROMETHEE and AHP (Analytic Hierarchy Process).

The most commonly used multi-criteria method, both in individual and group decision-making, is AHP.

In establishing the new scientific investment model, the AHP method was used, supported by the computer program Expert Choice. The method has often been described in detail in literature in the field of mathematics and related fields, so the rest of this paper only contains the basic characteristics (Saaty, 1980).

\subsubsection{AHP Method}

2.2.1. AHP metoda

AHP is one of the best known methods for making decisions through consistent evaluation of the hierarchy. Since this is an accurate mathematical model realized as PC software with full technical support, in the Expert Choice information format, it is applicable in multi-criteria decision-making. Solving complex decision-making problems is based on their division into components: goals, criteria, sub-criteria, alterna- 
Ojurović, Moro, Šegotić, Grladinović, Oblak: Analysis of the Investment in Wood... ........

Table 1 Scale for determining relevant importance (Saaty, 1980)

Tablica 1. Prikaz skale za određivanje relativnih važnosti (Saaty, 1980)

\begin{tabular}{|l|c|l|}
\hline $\begin{array}{l}\text { Verbal evaluation } \\
\text { Verbalna procjena }\end{array}$ & $\begin{array}{l}\text { Intensity of importance } \\
\text { Intenzitet važnosti }\end{array}$ & Explanation / Objašnjenje \\
\hline $\begin{array}{l}\text { extreme preference } \\
\text { ekstremna preferencija }\end{array}$ & 9 & $\begin{array}{l}\text { Favouring of one activity over another is proved at the highest } \\
\text { level. / Na najvišoj je razini dokazana prednost jedne aktivnosti } \\
\text { pred drugom. }\end{array}$ \\
\hline $\begin{array}{l}\text { very strong preference } \\
\text { vrlo stroga preferencija }\end{array}$ & 7 & $\begin{array}{l}\text { One activity is strongly favoured over another and its domi- } \\
\text { nance is proved in practice. / Jedna se aktivnost izrazito } \\
\text { favorizira u odnosu prema drugoj i njezina je dominacija } \\
\text { dokazana u praksi. }\end{array}$ \\
\hline $\begin{array}{l}\text { strong preference } \\
\text { stroga preferencija }\end{array}$ & $\begin{array}{l}\text { On the basic of experience and judgement, strong preference is } \\
\text { given to one activity. / Na osnovi iskustva i procjene daje se } \\
\text { izrazita prednost jednoj aktivnosti. }\end{array}$ \\
\hline $\begin{array}{l}\text { moderate preference } \\
\text { umjerena preferencija }\end{array}$ & $\begin{array}{l}\text { On the basic of experience and judgement, a slight preference is } \\
\text { given to one activity. / Na osnovi iskustva i procjene mala se } \\
\text { prednost daje jednoj aktivnosti. }\end{array}$ \\
\hline $\begin{array}{l}\text { equal importance } \\
\text { jednaka važnost }\end{array}$ & 1 & $\begin{array}{l}\text { Two activities contribute equally to the goal. } \\
\text { Dvije aktivnosti jednako pridonose cilju. }\end{array}$ \\
\hline $\begin{array}{l}\text { intermediate values } \\
\text { međuvrijednosti }\end{array}$ & $\begin{array}{l}\text { Compromise between respective adjacent value judgements. } \\
\text { Kompromis medu odgovarajućim susjednim vrijednosnim } \\
\text { procjenama. }\end{array}$ \\
\hline
\end{tabular}

tives and decision-makers, which are connected to the model with several levels (hierarchical structure), whereby the goal is at the top and the main criteria are on the first lower level. An important component of AHP is the possibility to account for the priorities (weights) of elements that are on the same level of the hierarchical structure.

An AHP evaluation is based on the decision maker's judgment about the relative importance of each criterion in terms of its contribution to the overall goal, as well as their preferences for the alternatives relative to each criterion. First we set up the decision hierarchy and then generated the input data consisting of comparative judgment (i.e. pairwise comparisons) of decision elements. A mathematical process (eingenvalue method) was used to calculate priorities of the criteria relative to the goal and priorities for the alternatives to each criterion. These priorities were then synthesized to provide a ranking of the alternatives in terms of overall preference.

In order to rank the priorities of investments, a questionnaire was developed that contains investment categories and intensity of importance. Due to its size, only a part of the questionnaire is presented in this paper. The fundamental scale to be used in making the comparison consists of verbal judgments ranging from equal to extreme. Corresponding to those verbal judg- ments are numerical judgments $(1,3,5,7,9)$ and compromises $(2,4,6,8)$ between these judgments. The scale for determining relevant importance is shown in Table 1 and an example of a part of the questionnaire for pairwise comparison in Figure 3.

Based on the results of the questionnaire, with the aid of a computer program, rankings of the observed investments were made.

\subsection{Collection and processing of data}

2.3. Prikupljanje i obrada podataka

The data collection method, within the research base period 2007 to 2010, entails the sample method as the main method, the content analysis as the secondary method and the questionnaire conducted amongst a representative sample of investors for obtaining primary data in the category of economic, social and financial indicators of investors. The method of data collection is in compliance with the goals and the method of the research, and it entails the sample method as the main method and content analysis as the secondary method. The source and type of data are primary and secondary.

Primary data are presented by category, size and structure of investments and the structure and size of the production program. The data was obtained from the following primary sources: investors - official fi-

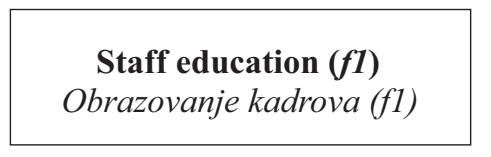

Marketing and promotional
activities $(f 2) /$ Marketing $i$
promotivne aktivnosti $(f 2)$

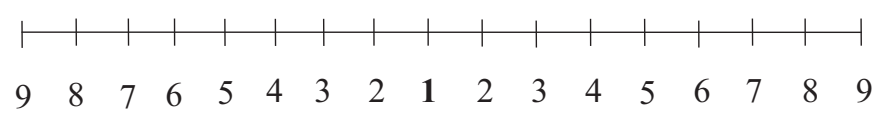

Figure 3 Example of a part of the questionnaire for pairwise comparison

Slika 3. Primjer dijela upitnika za uspoređivanje po parovima 
nancial and bookkeeping records and the relevant Ministry - official data contained in development projects, studies, pre-investment and investment projects of investors who applied, during the four-year period, for the awarding of specific-purpose grants of capital aid (horizontal state aid). Indicators for defining the main production program of investors, on the basis of which they are sorted into one of the three subareas of the population, also enter into the primary data.

Secondary data are presented by size of investor, number of employees on the basis of work hours, total revenue, share and structure of exports in total revenue. The data were gained from secondary sources: Central Bureau of Statistics - Državni zavod za statistiku (DZS, 2007) and the Financial Agency - Financijska agencija (FINA, 2006).

\section{RESEARCH RESULTS}

\section{REZULTATI ISTRAŽIVANJA}

\subsection{Existing investment model}

3.1. Postojeći model investicijskih ulaganja

The priority range of categories of investment of the population in the observed period 2007 to 2010 shows that the category $f 4$ and $f 6$ account for the largest share of investment (27\%) and (26\%), respectively, followed by $f 7(21 \%)$, with significant variation from the other lower value categories. Then follow $f 5(12 \%)$ and $f 2(11 \%)$, with approximately the same values. The penultimate category according to the value is $f 3(2 \%)$, and the last category is $f 1(1 \%)$ with an explicitly low share in the number of investments (Table 2).

Table 2 Number of investments according to factors from 2007 to 2010

Tablica 2. Broj investicija prema čimbenicima od 2007. do 2010. godine

\begin{tabular}{|c|c|c|c|c|c|}
\hline \multirow{2}{*}{$\begin{array}{c}\text { Factors } \\
\text { Čimbenici }\end{array}$} & \multicolumn{4}{|c|}{ Year / Godina } & \multirow[t]{2}{*}{$\Sigma$} \\
\hline & 2007 & 2008 & 2009 & 2010 & \\
\hline$f 1$ & 1 & 1 & 1 & 0 & 3 \\
\hline$f^{2}$ & 19 & 12 & 14 & 18 & 63 \\
\hline$f 3$ & 2 & 2 & 5 & 4 & 13 \\
\hline f4 & 28 & 34 & 37 & 50 & 149 \\
\hline$f 5$ & 11 & 21 & 14 & 16 & 62 \\
\hline f6 & 49 & 29 & 32 & 30 & 140 \\
\hline f7 & 31 & 43 & 25 & 19 & 118 \\
\hline$\Sigma$ & 141 & 142 & 128 & 137 & 548 \\
\hline
\end{tabular}

\subsection{AHP investment model of wood processing} and furniture manufacturing entities

3.2. AHP model investicijskih ulaganja gospodarskih subjekata prerade drva i proizvodnje namještaja

The main goal of this research is to establish the AHP investment model of wood processing and furniture manufacturing entities.

For the pairwise comparison, five professionals were recruited with expert knowledge in biotechnology, wood technology, social sciences and economics.

By using the questionnaire for Saaty's scale for comparing items in pairs and the AHP method, supported by the program Expert Choice, five preference matrixes were obtained on the basis of which the weights (priorities) of the alternatives were calculated.

The tabular presentation (Figure 5) gives the priorities of the alternatives by Expert A, whereby variable $\mathrm{L}$ is the priority of each alternative. Value 1 is the sum of the priorities. The Saaty scale is used to compare it (Table 1). For example, number 2 in the preference matrix of Expert A (Figure 4) shows that slight favour on the scale 1 to 9 is given to alternative $f 2$ in relation to alternative $f 1$. The value of number 3 shows that on a scale 1 to 9 favour is given to alternative $f 3$ and not to alternative $f 2$. Looking at the ranking of the alternatives by Expert A, it is undoubtedly evident that the largest priorities are alternative $f 1(0.337)$, followed by alternative $f 3(0.202)$.

The identification of the variation in individual judgements of the priority of the alternatives as part of the described method of the research in question was not carried out because of the possibility of visual observation of the homogeneity of the group. All five clusters are mutually very close in terms of their preferences, which demonstrates the homogeneity of the group.

\subsection{Comparative analysis of the existing and AHP investment model}

3.3. Usporedna analiza postojećeg modela i AHP modela investicijskih ulaganja

The main goal of the research in this paper was to develop an optimising and efficient investment model (AHP model) that would have practical application in wood processing and furniture manufacturing in the Republic of Croatia and would confirm the (un)acceptability of the existing investment model. The AHP model should be accepted as a pattern of ranking alternatives (priorities of investments in key factors of com-

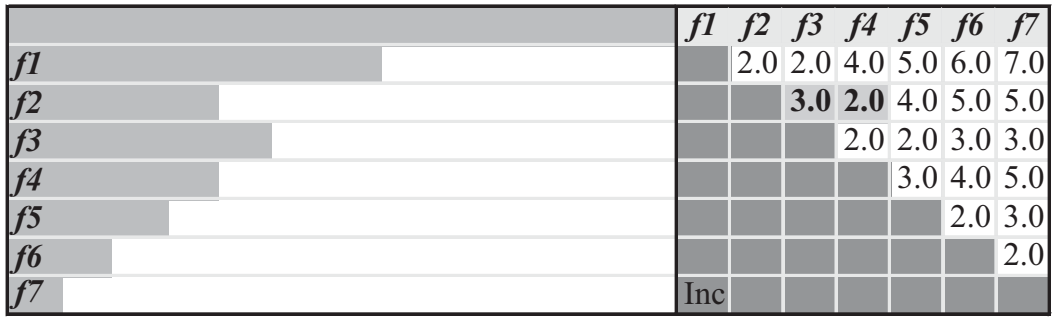

Figure 4 Preference matrix of expert A

Slika 4. Matrica preferencija eksperta A

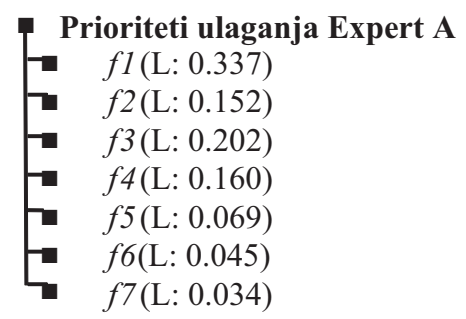

Figure 5 Ranking of alternatives of expert A

Slika 5. Rangiranje alternativa eksperta A 
Ojurović, Moro, Šegotić, Grladinović, Oblak: Analysis of the Investment in Wood... ........

Table 3 Group decision by experts A, B, C, D and E

Tablica 3. Skupna odluka eksperata A, B, C, D i E

\begin{tabular}{|c|c|c|c|c|c|c|c|c|}
\hline \multirow{2}{*}{$\begin{array}{c}\text { Factors } \\
\text { Cimbenici }\end{array}$} & \multicolumn{9}{|c|}{ Year/Godina } & \multirow{2}{*}{$\begin{array}{c}\text { Rank } \\
\text { Rang }\end{array}$} \\
\cline { 2 - 8 } & $\mathrm{A}$ & $\mathrm{B}$ & $\mathrm{C}$ & $\mathrm{D}$ & $\mathrm{E}$ & $\Sigma$ & $\Sigma / 5$ & 1 \\
\hline$f 1$ & 0.337 & 0.394 & 0.328 & 0.333 & 0.413 & 1,805 & 0.361 & 4 \\
\hline$f 2$ & 0.152 & 0.128 & 0.147 & 0.152 & 0.146 & 0.725 & 0.145 & 2 \\
\hline$f 3$ & 0.202 & 0.156 & 0.244 & 0.245 & 0.09 & 0.937 & 0.187 & 3 \\
\hline$f 4$ & 0.160 & 0.174 & 0.147 & 0.152 & 0.196 & 0.829 & 0.166 & 5 \\
\hline$f 5$ & 0.069 & 0.032 & 0.068 & 0.057 & 0.062 & 0.288 & 0.058 & 5 \\
\hline$f 6$ & 0.045 & 0.046 & 0.043 & 0.038 & 0.062 & 0.234 & 0.047 & 6 \\
\hline$f 7$ & 0.034 & 0.07 & 0.024 & 0.022 & 0.032 & 0.182 & 0.036 & 7 \\
\hline$\Sigma$ & 0.999 & 1.000 & 1.001 & 0.999 & 1.001 & 5.000 & 1.000 &
\end{tabular}

Table 4 Comparison of the existing and AHP investment models

Tablica 4. Usporedba postojećeg modela i AHP modela investicija

\begin{tabular}{|c|c|c|}
\hline $\begin{array}{c}\text { Rank } \\
\text { Rang }\end{array}$ & $\begin{array}{c}\text { Existing investment } \\
\text { model / Postojeći } \\
\text { investicijski model }\end{array}$ & $\begin{array}{c}\text { AHP investment } \\
\text { model / AHP } \\
\text { investicijski model }\end{array}$ \\
\hline 1 & $f 4$ & $f 1$ \\
\hline 2 & $f 6$ & $f 3$ \\
\hline 3 & $f 7$ & $f 4$ \\
\hline 4 & $f 2$ & $f 2$ \\
\hline 5 & $f 5$ & $f 5$ \\
\hline 6 & $f 3$ & $f 6$ \\
\hline 7 & $f 1$ & $f 7$ \\
\hline
\end{tabular}

petitiveness) that provides competitiveness in the long run, as determined by scientific knowledge. The results of comparison of the existing and of the AHP investment models are shown in Table 4.

Non-conformity in the priority ranking of five alternatives and the conformity of two alternatives of the observed investment models, confirm as follows:

1. the existing investment model of wood processing and furniture manufacturing entities in the Republic of Croatia does not support competitiveness and sustainable development,

2. investing in staff education, as a presumed key factor of competitiveness, is not at a satisfactory level and is an internal factor of wood processing and furniture manufacturing lagging behind in terms of competitiveness,

3. the systemisation and quality of investments have an effect on the achievement of excellence in business and production, which also contributes to preparedness for market changes,

4. the recommendations for the development of wood processing and furniture manufacturing in the Republic of Croatia, in terms of focussing on investments, as defined by the industrial wood and paper development strategy, are not operational.

\section{DISCUSSION AND CONCLUSION 4. DISKUSIJA I ZAKLJUČAK}

The existing model of ranking the key factors of competitiveness set the following ranking of priorities, from the highest to the lowest: wood processing and furniture manufacturing technology, energy efficiency, environmental protection, spatial capacities, marketing, innovation and, lastly, knowledge. The above presented ranking of priorities deviates entirely from the AHP investment model, which is accepted as a pattern of new development. This leads to the conclusion that the existing model is not acceptable for supporting the competitiveness and sustainable development of wood processing and furniture manufacturing.

The AHP investment model, which is established on scientific bases and takes into consideration generally-accepted knowledge and understanding and the results of expert and economic analyses, establishes the following ranking of the priority of key factors of competitiveness, from high to low: knowledge, innovation, wood processing and furniture manufacturing technology, marketing, environment, energy efficiency and, lastly, spatial capacities.

The AHP investment model should primarily be viewed within the context of the semi-finished and finished product subareas because the level of investment in the primary product subarea is limited. Products of a higher technological processing level and added value are a need imposed by the demands of the open market, but the fact that the primary processing level is essential for these products should not be neglected, or in other words, not all business entities can deal with value added products.

The new development direction has the logic of a series of key factors of competitiveness, according to which each lower factor in the series is dependent on the how the previous factor, of higher importance, is embedded into it.

Knowledge is the starting point of 'everything' and of all the factors of competitiveness. On the basis of knowledge, the idea of innovativeness is created which new products, services, processes - at what time - on which market - and how. Appropriate technology is required to produce something new. A new product needs to be directed at the market with the aim of being accepted and expecting an increasing demand for it, followed by marketing and promotional activities. When implementing the aforementioned factors of competitiveness, the principle of environmental protection must be observed, this being the basis of business and development strategies. Adherence to envi- 
ronmental standards and products, production and technology that are characterised by high energy efficiency are increasingly important elements of competitiveness, which requires the implementation of factors of energy efficiency technologies and, finally, spatial capacities as a material necessity.

The AHP optimising investment model is an indicator of the direction to be taken by wood processing and furniture manufacturing with the ultimate goal of achieving competitiveness and sustainability. The model demands systematic and simultaneous investment in all key factors of competitiveness, respecting the ranking of priorities as well as the size, efficiency and effectiveness of investment. Raising the level of competiveness and productivity through the development of modern types of production and expansion and at the same time the improvement of export quality can be achieved primarily through actions related to human potential. The following measures are essential to improve competitiveness: raising the general level of education, and in particular the development of human resources for the specific needs of business and production; systematic training aimed at improving the necessary knowledge and skills; the creation of an environment that encourages development and innovation; and a better networking of scientific institutions.

\section{REFERENCES}

\section{LITERATURA}

1. Debelić, B.; Štifanić, I.; Ojurović, R.; Debelić, B., 2009a: Utjecaj gospodarske krize na preradu drva i proizvodnju namještaja Republike Hrvatske, Sveučilišna knjižnica, CIP zapis dostupan u računalnom katalogu pod brojem 120422053, Rijeka, 104 pp.

2. Debelić, B.; Štifanić, I.; Ojurović, R., 2009b: Razvoj drvne industrije Primorsko-goranske županije utemeljen na znanju, CIP zapis dostupan u računalnom katalogu Sveučilišne knjižnice Rijeka pod brojem 120206016: Rijeka, $66 \mathrm{pp}$.

3. Ojurović, R., 2010: Model investicijskih ulagnja proizvodnih subjekata prerade drva i proizvodnje namještaja Republike Hrvatske u funkciji održivog razvoja, disertacija, Sveučilište u Zagrebu, Šumarski fakultet Zagreb, Zagreb, 1-133.

4. Saaty, T. L., 1980: The Analytic Hierarchy Process, New York: McGrew Hill. International, Translated to Russian, Portuguesses and Chinese, Revised edition, Paperback (1996, 2000), Pittsburgh: RWS Publications, 478 pp.

5. *** 2007: Pravilnik o razvrstavanju poslovnih subjekata prema nacionalnoj klasifikaciji djelatnosti - NKD 2002, NN 58/07.

6. *** 2007: Državni zavod za statistiku, Nacionalna klasifikacija prostornih jedinica za statistiku, NN 35/07.

7. *** 2007: Zakon o poticanju razvoja malog gospodarstva, Vlada Republike Hrvatske, NN 63/07.

8. *** 2006: Uredba o državni potporama, Vlada Republike Hrvatske, NN 121/03 i 50/06.

9. *** 2005: Zakon o državnim potporama, Vlada Republike Hrvatske, NN 140/05.

10. $* * * 2004$ : Strategija razvoja industrijske prerade drva i papira, Vlada Republike Hrvatske, Ministarstvo poljoprivrede, šumarstva i vodnoga gospodarstva, NN 114/2004, Zagreb.

\section{Corresponding addres:}

RENATA OJUROVIĆ, Ph.D.

Ministary of Agriculture, Republic of Croatia

Ulica grada Vukovara 220

HR - 10000 Zagreb

CROATIA

e-mail: renata.ojurovic@mrrsvg.hr 